\title{
İzlenim Yönetimi Taktikleri ile Yaşam Doyumu Arasındaki İlişki: Tekstil Sektörü Çalışanları Üzerine Bir Araştırma ${ }^{1}$
}

\author{
Zübeyde HASÇELTIK ${ }^{1 *(D)}$, Mehmet ÖZMEN² \\ ${ }^{1}$ Burdur Mehmet Akif Ersoy University, Burdur, Turkey
}

${ }^{2}$ Asst. Prof. Dr., Burdur Mehmet Akif Ersoy University, Bucak Faculty of Business, Department of Public Relations and Publicity, Burdur, Turkey

Geliş Tarihi/Received: 19.09.2019

Kabul Tarihi/Accepted: 01.10.2019
Doi: doi.org/10.31200/makuubd.622184

Araştırma Makalesi/Research Article

\section{ÖZET}

Bireyler, yaşamları boyunca içinde bulundukları ortam gereği diğer bireylerle etkileşim ve iletişim halindedirler. İçinde bulundukları ortamda da diğer bireylere amaçları doğrultusunda belirli izlenim oluşturmak isterler. Bunun için de izlenim yönetimi taktikleri davranışlarına başvururlar. Bireyler izlenim yönetimi taktiklerine başvurarak aslında maddi veya manevi kazanım elde etmek isterler. Bu bağlamda bireyin belirli taktikler kullanarak örgüt ortamlarında veya sosyal ortamlarda kazandıkları maddi ve manevi kazanımlar yaşamlarıyla yakından ilişskilidir.

Bu amaçla çalışma Denizli'de çeşitli tekstil fabrikalarında 392 mavi yakalı çalışan üzerinde gerçekleştirilmiştir. Araştırmada nicel araştırma yöntemleri uygulanmıştır. Kolayda örneklem tekniği ile anket uygulanarak elde edilen verilere fark testleri ve korelasyon analizi uygulanmıştır. Araştırma bulgularına göre, izlenim yönetimi taktikleri alt boyutu olan niteliklerini tanıtarak kendini sevdirmeye çalışma taktiği ile yaşam doyumu arasında anlamlı bir ilişkisi bulunmuştur. Diğer taraftan kendini örnek bir personel gibi göstermeye çalışma, kendi önemini zorla fark ettirmeye çalışma, kendine acındırmaya çalışma taktikleri ile yaşam doyumu arasında anlamlı bir ilişki tespit edilememiştir.

Anahtar kelimeler: İzlenim Yönetimi Taktikleri, Yaşam Doyumu, Tekstil Sektörü.

\footnotetext{
1 Bu çalışma birinci yazarın ikinci yazarın danışmanlığında hazırladığı yüksek lisans tezinden yararlanılarak hazırlanmıştır.

* Sorumlu yazar/Corresponding author

E-mail/e-ileti: zbyde.hasceltik@gmail.com 


\title{
The Relationship Between Impression Management Tactics and Life Satisfaction: A Research on the Workers in the Textile Industry
}

\begin{abstract}
Individuals interact and communicate with other individuals due to the environment they live in throughout their lives. They also want to create a certain impression on other individuals in the context of their purpose, and in order to do so, they resort to the behavior of the impression management tactics. Individuals actually want to obtain material or moral gains by applying to the tactics of impression management. In this context, by using certain tactics, the material and spiritual gains gained in organizational environments or social environments are closely related to their lives.
\end{abstract}

For this purpose, the study was conducted on 392 blue collar workers in various textile factories in Denizli. Quantitative research methods were applied in the research. The data obtained by applying the questionnaire with easy sampling technique and difference tests and correlation analysis were applied. According to the research findings, it was found that there is a meaningful correlation between the tactics of trying to endear themselves by introducing the qualities which is the sub-dimensions of impression management tactics with the life satisfaction. On the other hand, there is no meaningful correlation between trying to make themselves as model staff, trying to make realize their own importance, trying to arouse pity for with the life satisfaction.

Keywords: Impression Management Tactics, Life Satisfaction, Textile Sector.

\section{GİIŞ}

Son yıllarda tüm dünyada yaygınlaşan küreselleşme, teknolojik değişim, yeni pazar arayışları veya müşteri beklentilerinin değişmesi gibi nedenlerle yoğun bir şekilde rekabet ortamı oluşmakta bu rekabet ortamı içerisinde de işletmeler varlıklarını devam ettirebilmek için veya kar oranlarını artırabilmek amacıyla faaliyetlerini sürdürmektedirler. Bu sert rekabet koşulları içerisinde işletmelerin etkinlik ve verimliliklerini devam ettirmesinde rol alan unsurların başında ise insan faktörü gelmektedir. İşletmeler iş görenleri sadece üretim faktörü olarak görmek yerine iş görene ve onun değerlerine önem vermelidir. Yani sert rekabet koşulları içerisinde işletmelerin amaçlarına ulaşmasındaki en önemli etkenlerden biri işletme bünyesinde çalışan iş görenlerdir. İş görenlerin performansları, iletişimleri gibi etkenler işletmelerin 
verimliliği ve etkinliğini etkilemektedir. İşletmede çalışan iş görenler maddi ve manevi kazanıma ulaşmak için çalıştığı ortamda diğer kişilere karşı veya yönetim kademesinde çalışan kişilere karşı onların kendisi hakkında düşünülen algılamaları etkileyerek kendi istediği şekilde bir kimlik veya imaj oluşturmak için bazı davranışları sergilemeye yönelirler. Bu etkileme ve yönlendirme amacı ile yaptığı davranışlarında da izlenim yönetimi taktiklerine başvurmaktadır.

Bireyler, diğer bireylere karşı veya yönetim kademesinde bulunanlara karşı kullandıkları izlenim yönetimi taktikleri neticesinde bir geribildirim almaktadır. Aldıkları geribildirimler bireylerin yaşamlarına olumlu veya olumsuz olarak etki etmektedir.

\section{KAVRAMSAL ÇERÇEVE}

\section{1. İzlenim Yönetimi ve Taktikleri}

İzlenim yönetimi kavramı başlangıçlarda sosyologlar ve sosyal psikologlar tarafından incelenmiş olmakla birlikte, son yıllarda örgütsel davranış araştırmacıları tarafından da ilgi duyulmaya başlanmıştır. Günümüzde de örgütlerde izlenim yönetimi giderek önemini artırmaktadır (Bolino ve Turnley, 1999: 187). Bozeman ve Kacmar (1997: 9)'a göre izlenim yönetimi, kişilerin kendi algılamaları ile ilgili belirledikleri hedefe ulaşmak için, sözlü veya sözlü olmayan davranışa başvurdukları stratejik bir süreçtir. Diğer bir tanımda ise kişilerin arzu ettikleri sonuca ulaşabilmek için izlenmesi gereken sistemli davranışlardır (Chen ve Fang, 2008: 264). İzlenim yönetimi, izlenimi yapan kişinin hedeflerine odaklanır. Bireyler, karşısındaki kişilerin bazılarına bir kısım özelliklerini bazılarına da farklı özelliklerini ön plana çıkarmayı tercih ederler (DePaulo, 1992). Bu bağlamda izlenim yönetimi, diğer bireylere karş1 göstermek istediğimiz şekilde görülmemizi sağlamak olarak ifade edilebilir (Aronson vd., 2010: 289).

Kişiler sosyal ve örgütsel ortamlarda diğer kişiler üzerinde izlenim oluşturmaya çalıştırmaktadırlar. Bu izlenimler, kişinin diğer insanlarla ilişkilerinin gelişmesinde, kendisinin ve diğer kişilerin algılarının oluşmasında, değerlendirmelerin yapılmasında ve karar almada etki göstermektedir. Bu durumun bilincinde olan birey kendisi için oluşacak izlenimi yönetmek veya yönlendirmek isteyebilir. Bireyin bu şekilde yönetmek ve yönlendirmek isterken kontrol etmek amacı doğal bir davranış olarak karşımıza çıkmaktadır (Basım vd., 2006a: 2). Buradan hareketle kişinin kendisine karşı oluşturulan izlenimleri kontrol altında tutmaya çalışması, çeşitli bireysel amaçlara yönelik bir davranış şekli olarak karşımıza çıkmaktadır. Bu kontrol etme çabası yönetme ve yönlendirmeyle birlikte devamında birçok taktiğin uygulanmasını beraberinde getirmektedir (Çetin ve Basım, 2010: 256). 
İzlenim yönetimi taktiklerine yönelik literatürde farklı sınıflandırmalar yapılmıştır. Jones ve Pittman (1982)'nın sınıflandırmasında kendini sevdirmeye, niteliklerini göstermeye, kendini örnek personel göstermeye, kendini acındırmaya çalışma ve tehdit etme taktiği yer almaktadır. Wayne ve Feris (1990) iş, yönetici ve öz odaklı olmak üzere üçlü bir sınıflandırma yapmıştır. Schütz (1998) dörtlü bir sınıflandırma yapmış; kendini göstermeye yönelik, saldırgan, korunmaya yönelik ve savunmaya yönelik taktikler olarak belirtmiş̧ir. Crane ve Crane (2002) ise girişken ve savunmaya yönelik taktik sınıflandırması yapmıştır. Bolino ve Turnley (1999) ise Jones ve Pittman (1982)'ın çalışmasından hareketle benzer bir sınıflandırma yapmış ve ölçek geliştirmişlerdir. Bu taktikler; niteliklerini tanıtarak kendini sevdirmeye, karşıdakini yücelterek kendini sevdirmeye, kendini örnek bir personel olarak göstermeye, kendi önemini zorla fark ettirmeye ve kendine acındırmaya çalışma taktiğidir.

İzlenim yönetimi her ne kadar olumlu görünen bir kavram olsa da bazı durumlarda olumsuz sonuçlara neden olabilmektedir (Demiral, 2016: 46). İzlenim yönetimi davranışları, örgütsel yaşamın her kademesinde görülebilir. Burada önemli olan davranışların hangisinin dürüst ve doğal, hangisinin de doğal olmayan davranış olduğunu ayırabilmektir (Basım ve Tatar, 2006: 242). Buradan hareketle, yönetici çalışanların samimi davranışlarla yapmacık davranışlarını ayırt edebilmelidir. Eğer yönetici bu izlenim yönetimi davranışlarını ayırt edemez ise bu durum yanlış performans değerlendirmesine neden olmakla birlikte örgüt ve diğer çalışanlar için olumsuz bir durum ortaya çıkarabilecektir (Doğan ve Kılıç, 2009: 79).

İzlenim yönetimiyle ile ilgili literatür incelendiğinde bu konuda çeşitli alanlarda çalışmalar yapıldığı görülmektedir. Demir (2002) tarafından yapılan araştırmada öğretmenlerin kendini tanıtmaya yönelik izlenim yönetimi taktiklerinden en fazla örnek olma taktiği, kendini savunmaya yönelik taktiklerden ise en fazla özür dileme taktiklerini kullandıkları tespit edilmiştir. Ünaldı (2005) tarafından emniyet teşkilatında çalışan yöneticiler üzerinde yaptı̆̆ araştırmada, yöneticilerin kendini tanıtmaya yönelik izlenim yönetimi taktiklerinden en fazla kullandıkları taktiğin övgü taktiği, en az kullandığı taktiğin vurgulama taktiği olduğunu bulmuştur. Kendini savunmaya yönelik izlenim yönetimi taktiklerinden ise en fazla kullandığı taktiğin özür dileme taktiği, en az kullandığı taktiğin engel koyma taktiği olduğu sonucuna ulaşmıştır.

Meydan (2011) tükenmişliğin izlenim yönetimi ile olan ilişkisini banka çalş̧anları bağlamında araştırmıştır. Duygusal tükenmenin kendini acındırma izlenim yönetimi taktiğini, duyarsızlaşmanın kendi önemini zorla fark ettirme taktiğini, kişisel başarı hissi azalmasının 
kendini sevdirme ve kendini acındırma taktiklerini yordadığı bulgularına ulaşmıştır. Serin vd. (2014) ise çatışma yönetim ve stratejileri ile izlenim yönetimi taktikleri arasındaki ilişkiyi araştırmıştır. Araştırma sonuçlarına göre çatışma yönetimi alt boyutlarından olan uzlaşma ile tehdit ve kendini sevdirme taktiği, hükmetme ile tehdit ve kendine sahip çıkma taktikleri, tümleştirme ile kendini sevdirme ve işe sahip çıkma taktikleri arasında anlamlı ilişkiler bulmuştur.

Erhardt ve Gibbs (2014), yöneticiler ve astlar arasındaki ilişkilerde izlenim yönetimi taktiklerinin medya üzerinden uygulanmasına odaklanmıştır. Yavuz (2018) da üniversite öğrencilerinin sosyal medyada kullandıkları izlenim yönetimi taktiklerinin benlik saygısı ile ilişkisini araştırmış, aralarında negatif yönde anlamlı bir ilişki bulmuştur.

Mumcu (2018) örgüt iklimi, örgütsel sinizm, lider-üye etkileşimi ile izlenim yönetimi taktikleri arasındaki ilişkileri araştırmıştır. Araştırma sonuçlarında, izlenim yönetimi taktiklerinin sinizm algısı üzerinde pozitif yönlü etkisi tespit edilmiştir. Bektaş ve Karagöz (2018) izlenim yönetimi taktiklerinin işe tutkunluğa etkisini araştırmış ve pozitif yönde etkilediğini bulmuştur.

\subsection{Yaşam Doyumu Kavramı}

Yaşam doyumu, ilk defa Neugarten vd. (1961) tarafindan ortaya atılan ve bilim dünyasına kazandırılan bir kavramdır. Yaşam doyumu, bireyin beklentileri ile gerçek yaşamdaki durumları karşılaştırmasıdır. $\mathrm{Bu}$ karşılaştırma sonucunda bireyin yaşamı değerlendirmesinde kendi hayatında önemli olarak gördüğü şeylere dayanması ve bireyin kendi değerlendirmesinden oluşmaktadır (Beyhan, 2018: 42-43). Yaşam doyumu bireyin bütün yaşamını kapsamakta ve bu yaşama dair tüm boyutları içermektedir. Yaşam doyumu mutluluk ve iyi olma olarak da ifade edilmektedir (Acar, 2010: 9). Her ne kadar yaşam doyumu kavramının eş anlamlıları mutluluk ve öznel iyi oluş kavramları olarak görülse de mutluluk kavramı daha çok objektif bir iyilik durumu ifade etmektedir, yaşam doyumu kavramı ise subjektif özelliğinin vurgulanması olarak ifade edilmektedir (Veenhoven, 1996: 6). Subjektif olmasının sebebi ise araştırmalarda bireylere basit bir şekilde genel olarak hayatlarından tatmin olup olmadıkları sorulmaktadır (Yiğit vd. 2011: 4).

Yaşam doyumu kavramı, günümüze kadar farklı araştırmacılar tarafindan ve farklı araştırmalarda üzerinde durulan bir konu olmaktadır. Bireylerin, kendilerini ve çevresini algılama biçimlerini, duygu ve düşüncelerden etkilenme biçimlerini araştırma konusu yapan 


\section{Hasçeltik, Z. \& Özmen, M.}

yaşam doyumu kavramı üzerinde geniş bir literatüre ulaşılmaktadır. Yaşam doyumu kavramının ne olduğu, ifade etme biçimi ve hangi konularla ilgili olduğuyla alakalı birçok tanım yapılmaya çalışıllmıştır (Toy, 2015: 15). Yaşam doyumuna ait tüm dünyada, çeşitli alanlarda uzun süren çalışmalar sonucunda kesin olarak tek bir tanım yapılamamasıyla beraber, farklı araştırmacılar ve farklı çalışma alanlarında bazı tanımlamalar yapılmıştır (Etiler, 2017: 25). Literatürde yaşam doyumu hakkında yapılan bazı tanımlamalar aşağıda yer almaktadır.

Yaşam doyumu, bir kişinin günlük yaşamındaki aktiviteleri, sorumlulukları, hayatlarının anlamı, hedeflerine ulaşması, olumlu yönde bir egoya sahip olması, iyimser bir tutum sergilemesi olarak tanımlanmaktadır (Sung, 2003: 1094). Bu bağlamda yaşam doyumunu, kişinin hayatının bütününe yönelik olumlu bir tutum şeklinde ifade etmek mümkündür (Jan ve Masood, 2008: 33). Yaşam doyumu, kişinin yaşam kalitesini bir bütün olarak olumlu bir şekilde değerlendirme derecesidir. Diğer bir ifadeyle kişinin yaşadığı hayatı ne kadar sevdiğidir (Veenhoven, 1996: 6).

İnsanların yaşadıkları hayat boyunca mutlu olabilmeleri ve yaşamlarının bir anlam kazanabilmesi için, temel unsurların başında yaşam doyumu gelmektedir (Yiğit, vd., 2011: 3). Bu bağlamda yaşam doyumu, bireylerin hayatın geneline ve örgütsel çevreye ilişkin olumlu tutum ve davranışlar göstermeleri üzerinde önem taşıyan unsur olarak ifade edilmektedir. Bireylerin yaşam doyumuna sahip olmaları, iş ve örgütsel çevrede bununla birlikte çalışma dışında kalan aile, akraba ve arkadaş çevresinde de pozitif davranışlar sergilemesine neden olmaktadır (Kanten ve Kanten, 2015: 60).

Buna ek olarak çalışan bireylerin iş hayatında ve iş dışı hayatında sağlıklı bir denge kurması halinde; yüksek üretkenlik ve çalışma verimliliği sağlanmakta, çalışan bireyler işletmelerde daha uzun süre tutulabilmekte, işletmeler kendi bünyelerine kaliteli ve daha çok personel katabilmekte, örgütlerde daha az oranda hastalık ve işe devamsızlık olayı yaşanmakta, çalışanların moral seviyeleri ve bağlılıklarında da artış olmaktadır. İş ve yaşam dengesinin elde edilmesiyle bireyler olaylara karşı daha net ve keskin, aynı zamanda daha yaratıcı olmakla birlikte daha motivasyonlu olmaları sağlanmaktadır (Morgenstern, 2004: 28-32). Bu bağlamda yaşam doyumu kavramını iş hayatımızdan ayırmak mümkün olmayacaktır. Bunun sebebi ise, bireyin yaşam doyumunda hayatında oldukça önemli yer tutan iş hayatının olmasıdır (Keser, 2005: 80). 
Sonuç olarak gerek işletmelerde gerekse toplumsal ilişkilerde insana verilen önem artış göstermektedir. Bireyin duyguları, algılamaları, mutlu olması gibi psikolojik durumları artık gün geçtikçe örgütlerin vazgeçilmez bir bileşeni haline gelmektedir (Y1lmaz ve Sünbül, 2009: 173). Bu bağlamda örgütlerde çalışan bireylerin iş hayatından doyum almaları yaşam doyumlarını ve üretkenliğinde de önemli rol oynamaktadır. Örgütlerde çalışan bireyler yaşam doyumuna olumlu veya olumsuz etki eden faktörleri ortaya koyarak daha fazla doyum ile birlikte daha az tükenme yaşaması örgütsel amaçlara ulaşmada önemlidir (Ünal vd., 2001: 114).

Literatürde yaşam doyumu ile ilgili çalışmalara bakıldığında çok farklı alanlarda ve değişkenlerle ilişskilerinin araştırıldığı görülmektedir. Diener vd., (2000), ülkelerin genel yaşam doyumlarını incelemiş, ilk üçte İspanya, Amerika, Tayland çıkmıştır. Chow (2005) ise üniversite öğrencisine yaşam memnuniyeti araştırması yapmış, not ortalaması ve sosyoekonomik durumu yüksek olan ile, akademik deneyimi, özgüveni, diğer bireylerle ilişkileri ve yaşam şartlarından daha yüksek doyum sağlayanların, daha fazla yaşam doyumu sağladıkları bulgularına ulaşmıştır. Benzer bir çalışma Dost (2007) tarafından yapılmış üniversite öğrencilerinin yaşam doyumlarının bazı sosyo-ekonomik ve demografik özelliklerine göre farklılaştığını bulmuştur.

Aysan ve Bozkurt (2004) psikolojik danışmanların, yaşam doyumu, stresle başa çıkma stratejileri ve olumsuz otomatik düşünceleri arasındaki ilişkileri araştırmış ve aralarında anlamlı ilişkiler bulmuştur. Eroğul ve Örkün (2012) iş doyumu, tükenmişlik ve yaşam doyumu ilişkilerini araştırmış, iş doyumunu en çok yordayan değişkenin duygusal tükenme olduğunu tespit etmiştir. Şimşek ve Aktaş (2015) yalnızlık ve yaşam doyumu ilişkisinde iletişim becerilerinin rolünü sorgulamış, yalnızlık ve yaşam doyumu arasında negatif ve güçlü bir ilişki, iletişim becerilerinin yalnızlıkla olumsuz, yaşam doyumu ile olumlu yönde bir ilişkisi bulmuştur. Dal (2015) ise duygusal zekâ ile yaşam doyumu arasındaki ilişkiyi araştırmış, aralarında pozitif yönde bir ilişsi bulmuştur.

Fakunmoju (2018) iş etiği ve yaşam doyumunda cinsiyetin etkisini araştırmış, kadınlarda iş etiğinin erkeklere göre yaşam doyumlarını daha çok etkilediğini tespit etmiştir. Elevli ve Bayram (2019) yaşam doyumunun iş doyumu üzerindeki etkisinde sosyal zekanın aracılık etkisini belirlemek amacıyla bir araştırma yapmıştır. Sosyal zekanın iş doyumu üzerinde, yaşam doyumunun iş doyumu ve sosyal zekâ üzerinde pozitif etkisin, yaşam doyumunun iş doyumu üzerindeki etkisinde sosyal zekanın kısmı aracılık etkisinin olduğunu bulmuştur. 
Acaray ve Günsel (2017) beş faktör kişilik özellikleri, izlenim yönetimi taktikleri ve öznel iyi oluş arasındaki ilişkileri araştırmıştır. Araştırmanın sonuçlarına göre, izlenim yönetimi taktikleri alt boyutlarından olan kendini sevdirme taktiği yaşam doyumu üzerinde pozitif, kendine acındırma taktiği ise negatif ve anlamlı bir etkiye sahiptir. Ayrıca kendini örnek çalışan gösterme taktiği, pozitif duygulanım üzerinde negatif ve anlamlı bir etkiye sahiptir.

Yapılan araştırmalar incelendiğinde yaşam doyumuna etkileyen birçok unsurun olduğu göze çarpmaktadır. Kişinin hedeflerine ulaşmak ve başkalarının nezdinde oluşturmak istediği izlenime yönelik davranışlarını şekillendirmesinin de yaşam doyumları ile ilişkilendirilebileceğinden hareketle hipotezler oluşturulmuştur. Nitekim bu yönde yapılmış az sayıdaki araştırmaların (Acaray ve Günsel, 2017) sonuçları da bunu destekler niteliktedir.

\section{ARAŞTIRMANIN METODOLOJISI}

\subsection{Araştırmanın Amacı ve Önemi}

Bireyler yaşamlarının çoğu zamanını çalışma ortamlarında geçirmekte ve sürekli olarak başka kişilerle etkileşim halinde olmaktadır. Çalışma ortamında veya sosyal hayatta karşılaşılan durumlar da bireyin yaşam doyumu düzeyini etkilemektedir. Bu bağlamda araştırmanın ana amacı kullanılan izlenim yönetimi taktikleri ile yaşam doyumu arasındaki ilişkiyi incelemektir. Çalışmanın alt amacı ise, izlenim yönetimi taktikleri alt boyutları ile yaşam doyumunun çalışanların cinsiyet, yaş, medeni durum, eğitim, gelir, mesleki tecrübe ve iş yerindeki tecrübe değişkenleri açısından farklılık olup olmadığını araştırmaktır.

\subsection{Evren ve Örneklem}

İzlenim yönetimi taktikleri ve yaşam doyumu arasındaki ilişkiyi araştırmak için yapılan araştırmada evreni Denizli ilindeki tekstil fabrikalarında mavi yakalı çalışanlar oluşturmaktadır. Araştırmada kolayda örnekleme yöntemiyle tekstil fabrikalarında çalışanlara ulaşılmış, eksik veya hatalı doldurulan anketler çıkarıldıktan sonra analizler 392 mavi yakalı çalışan üzerinden gerçekleştirilmiştir.

\subsection{Veri Toplama Araçları}

Araştırma nicel veri toplama araçlarından biri olan anket yöntemi ile gerçekleştirilmiştir. Anket formu demografik ve mesleki özellikler soruları, izlenim yönetimi taktikleri ve yaşam doyumu ölçeğinden oluşmaktadır. 
Araştırmada Bolino ve Turnley (1999) tarafindan geliştirilen, Basım vd. (2006) tarafından Türkçe uyarlanan izlenim yönetimi taktikleri ölçeğinden yararlanılmıştır. Ölçek 5 boyut ve 22 ifadeden oluşmaktadır. Çalışmada ölçeğin tümü için hesaplanan güvenirlik katsayısı $\alpha=.82$ ölçekte yer alan faktör alt ölçekler için güvenirlik katsayısı .57 ile .74 arasında olduğu tespit edilmiştir. Ayrıca yapılan analizler sonucunda ölçeğin orijinal yapısına benzer bir faktör yapısı gösterdiği bulunmuştur. İzlenim yönetimi taktikleri ölçeğinde 5'li likert tipi derecelendirmesi yapılmış ve anket formundaki ifadeler " 1 : Hiçbir Zaman, 2: Nadiren, 3: Ara Sıra, 4: Genellikle, 5: Her Zaman”’ şeklinde kodlanmıştır.

Yaşam doyumu için Diener vd. (1985) tarafından geliştirilen "Yaşam Doyumu Ölçeği”" kullanılmıştır. Özgün ölçek tek faktörlü bir yapı halinde 5 ifadeden oluşmaktadır. Ölçeğin Türkçe'ye uyarlaması ise Dağlı ve Baysal (2016) tarafından yapılmıştır. Çalışmada ölçeğin tümü için güvenirlik katsayısı $\alpha=.88$ olarak hesaplanmıştır. Yaşam doyumu ölçeğinde 5'li likert tipi derecelendirmesi yapılmış ve anket formundaki ifadeler " 1 : Kesinlikle Katılmıyorum, 2: Katılmiyorum, 3: Ne Katılıyorum Ne Katılmıyorum, 4: Katıliyorum, 5: Kesinlikle Katılıyorum'” şeklinde kodlanmıştır.

\subsection{Veri Toplama Araçlarının Geçerlilik ve Güvenilirlikleri}

Araştırmada kullanılan ölçeklerin öncelikle yapısal açıdan geçerli olup olmadıklarını sınamak için doğrulayıcı faktör analizi (DFA) yapılmıştır. İzlenim yönetimi taktikleri ölçeğine ilişkin modifikasyon önerileri doğrultusunda NT1 ve NT3, NT3 ve NT8, NT7 ve NT8, KAC1 ve KAC2 kovaryans bağlantısıyla yapılarak birbirine bağlanmıştır. Bununla birlikte yapılan ölçüm sonucunda istenilen yük değeri taşımaması ve uyum indeksi değeri düşürmesi nedeniyle NT5, KOB4 soruları ve işine sahip çıkmaya çalışma boyutunu ölçen ISCC1 VE ISCC2 soruları modelden çıkarılarak analize dahil edilmemiştir. Tüm bu modifikasyon işlemleri neticesinde elde edilen uyum indeksleri $\left(\mathrm{x}^{2}=406,03 \mathrm{df}=124\right) \mathrm{x}^{2} / \mathrm{df}=3,27, \mathrm{RMSEA}=0,076, \mathrm{GFI}=0,90$, AGFI $=0,86, \mathrm{NFI}=0,94$ ve $\mathrm{CFI}=0,96$ olarak saptanmıştır. İzlenim yönetimi taktikleri ölçeğinde dört boyutlu bir yapı ortaya çıkmıştır.

Yaşam doyumu ölçeğinde ise YD3 ve YD4 arasında modifikasyon işlemi yapılarak birbirine bağlanmıştır. $\mathrm{Bu}$ modifikasyon işlemi sonucunda elde edilen uyum indeksleri $\left(x^{2}=15,22 \mathrm{df}=4\right) \mathrm{x}^{2} / \mathrm{df}=3,80, \mathrm{RMSEA}=0,085, \mathrm{GFI}=0,98, \mathrm{AGFI}=0,94, \mathrm{NFI}=0,99$ ve $\mathrm{CFI}=0,99$ olarak saptanmıştır. Her iki ölçekten elde edilen fit değerleri Aksu vd., (2017: 79) göre oluşturulan modelin anlamlı ve kabul edilebilir düzeyde olduğunu göstermektedir. 


\subsection{Araştırmanın Modeli ve Hipotezleri}

İzlenim yönetimi taktikleri alt boyutlarından olan niteliklerini tanıtarak kendini sevdirmeye çalışma, kendini örnek bir personel gibi göstermeye çalışma, kendi önemini zorla fark ettirmeye çalışma ve kendine acındırmaya çalışma taktikleri ile yaşam doyumu arasındaki ilişki üzerine araştırma modeli kurulmuştur.

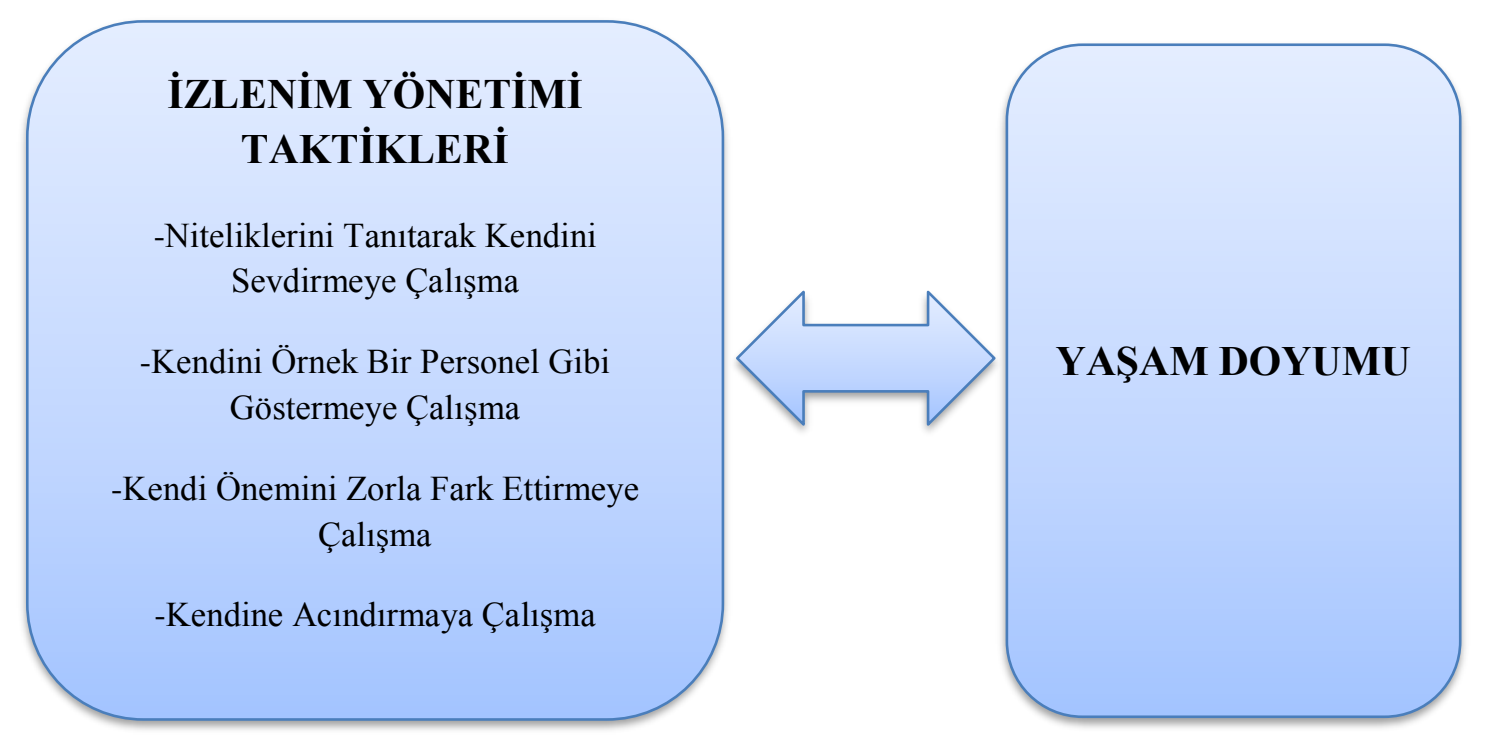

Şekil 1. Araştırma modeli

Araştırma modeli doğrultusunda oluşturulan hipotezler şunlardır:

H1: Niteliklerini tanıtarak kendini sevdirmeye çalışma taktiği ile yaşam doyumu arasında istatistiksel olarak anlamlı bir ilişki vardır.

H2: Kendini örnek bir personel gibi göstermeye çalışma taktiği ile yaşam doyumu arasında istatistiksel olarak anlamlı bir ilişki vardır.

H3: Kendi önemini zorla fark ettirmeye çalışma taktiği ile yaşam doyumu arasında istatistiksel olarak anlamlı bir ilişki vardır.

H4: Kendine acındırmaya çalışma taktiği ile yaşam doyumu arasında istatistiksel olarak anlamlı bir ilişki vardır.

\subsection{Bulgular}

Araştırmaya katılan tekstil fabrikalarında çalışan bireylerin demografik özelliklerine incelendiğinde, \%59,9'u kadın, \%40,1' i erkektir. \%14,8'i 25 yaş ve altı, \%30,6's1 26-35, $\% 43,4$ 'ü 36-45, \%10,7'si 46-55, \%05'i ise 56 yaş ve üzerindedir. \%76,5'i evli, \%23,5'i 
bekârdır. \%39'unun ilkokul, \%18,4'ünün ortaokul, \%28,1'inin lise, \%6,1'inin önlisans, \%6,1'inin lisans, \%2,3'ünün ise lisansüstü eğitim durumuna sahip olduğu tespit edilmiştir. \%28,3’ü 2000 ve altı gelir düzeyinde, \%57,7'si 2001-2500 gelir düzeyinde, \%9,9’u 2501-3500 gelir düzeyinde, \%4,1'i ise 3501 ve üzeri gelir düzeyine sahiptir. \%31,6's1 5 y1l ve daha az, \%13,8'i 6-10 yıl aras1, \%19,6's1 11-15 y1l aras1, \%15,6's1 16-20 y1l aras1, \%10,5'i 21-25 y1l arası, \%8,9'u 26 y1l ve üzerinde mesleki tecrübeye sahiptir. \%59,7'si 5 y1l ve daha az, \%15,6's1 6-10 yıl arası, \%15,1'i 11-15 yıl arası, \%7,1'i 16-20 yıl arası, \%2,6'sı 21 yıl ve üzeri işyeri tecrübesine sahiptir.

\section{7. Ölçeklere İlişkin Bulgular}

Tablo 1'de ölçeklerin güvenilirliğine yönelik iç tutarlılık katsayıları, normal dağılım gösterip göstermediğine yönelik çarpıklık ve basıklık değerleri ile ortalama ve standart sapma değerleri verilmiştir.

Tablo 1. Ölçeklerin güvenilirlik, normallik ve ortalama değerleri

\begin{tabular}{|l|c|l|l|l|l|l|}
\hline Ölçek ve Alt Boyutlar & Madde S. & Çarpıklık & Basıklık & $\boldsymbol{\alpha}$ & Ort. & Ss. \\
\hline $\begin{array}{l}\text {-Niteliklerini Tanıtarak Kendini } \\
\text { Sevdirmeye Çalışma (NTKSC) }\end{array}$ & 7 &, 669 &,- 236 &, 826 & 2,23 & 0,95 \\
\hline -Kendine Acındırma Çalışma (KAC) & 5 & 1,018 &,- 132 & 0,643 & 1,26 & 0,36 \\
\hline $\begin{array}{l}\text {-Kendini Örnek Bir Personel Gibi } \\
\text { Göstermeye Çalışma (KOBPGGC) }\end{array}$ & 3 & 1,888 & 1,909 & 0,667 & 1,51 & 0,62 \\
\hline $\begin{array}{l}\text {-Kendi Önemini Zorla Fark Ettirme } \\
\text { Çalışma (KOZFC) }\end{array}$ & 3 & 1,428 & 1,122 & 0,802 & 1,24 & 0,41 \\
\hline -Yaşam Doyumu (YD) & 5 &,- 215 &,- 567 & 0,829 & 3,14 & 1,01 \\
\hline
\end{tabular}

Tablo 1'den elde edilen bulgulara bakılarak en yüksek ortalama değere niteliklerini tanıtarak kendini sevdirmeye çalışmak taktiği sahipken, kendi önemini zorla fark ettirmeye çalışma taktiğinin ise en düşük ortalama değere sahip taktik olduğu görülmektedir. Yaşam doyumu ölçeğinin ise ortalama değerinin 3,14 olduğu görülmektedir. Verilerin normalliği için Çarpıklık (Skewness) ve Basıklık (Kurtosis) değerleri incelenmiştir. Bu değerlerin +2 ile -2 aralığında olması verilerin normal dağılım olduğuna işaret etmektedir (Trochim ve Donnelly, 2006; Field, 2009). Cronbach Alpha katsayıları da ölçeklerin oldukça güvenilir olduğunu göstermektedir (İslamoğlu ve Alnıaçık, 2014). 


\subsection{Fark Testi Bulguları}

Araştırmada katılımcıların izlenim yönetimi taktiklerinin ve yaşam doyumlarının demografik özelliklerine göre farklılaşıp farklılaşmadığı bağımsız örneklem $t$ testi ve ANOVA testi ile analiz edilmiştir.

Tablo 2. İzlenim yönetimi taktikleri ile yaşam doyumu düzeylerinin cinsiyete göre farklılığını gösteren bağımsız örneklem $\mathrm{t}$ testi

\begin{tabular}{|c|c|c|c|c|c|c|c|c|}
\hline \multirow{2}{*}{ Faktörler } & \multicolumn{2}{|c|}{ Kadın } & \multicolumn{2}{c|}{ Erkek } & \multicolumn{3}{c|}{ Ortalamaların Homojenliğiyle İlgili t Testi } \\
\cline { 2 - 10 } & Sayı & Ort. & Sayı & Ort. & F & T & df & Sig.(p) \\
\hline NTKSC & 235 & 2,054 & 157 & 2,490 & 0,744 & $-4,596$ & 390 & $\mathbf{0 , 0 0 0}$ \\
\hline KOBPGGC & 235 & 1,383 & 157 & 1,699 & 4,045 & $-5,041$ & 390 & $\mathbf{0 , 0 0 0}$ \\
\hline KOZFC & 235 & 1,160 & 157 & 1,378 & 26,00 & $-5,185$ & 390 & $\mathbf{0 , 0 0 0}$ \\
\hline KAC & 235 & 1,195 & 157 & 1,364 & 16,32 & $-4,592$ & 390 & $\mathbf{0 , 0 0 0}$ \\
\hline YD & 235 & 3,160 & 157 & 3,113 & 0,068 & 0,452 & 390 & 0,652 \\
\hline
\end{tabular}

Bağımsız örneklemler t-Testi sonucunda, izlenim yönetimi taktikleri alt boyutlarının cinsiyete göre anlamlı bir farklılık gösterdikleri $(p<0,05)$ bulgularına ulaşılmıştır. İzlenim yönetimi taktikleri alt boyutlarının hepsinde erkek çalışanların ortalamalarının kadın çalışanlara göre daha yüksek olduğu görülmektedir. Yaşam doyumu düzeyinde ise anlamlı bir farklılık görülmemektedir $(\mathrm{p}>0,05)$.

Tablo 3. İzlenim yönetimi taktikleri ile yaşam doyumu düzeylerinin medeni duruma göre farklılığını gösteren bağımsız örneklem $\mathrm{t}$ testi

\begin{tabular}{|c|c|c|c|c|c|c|c|c|}
\hline \multirow{2}{*}{ Faktörler } & \multicolumn{2}{|c|}{ Evli } & \multicolumn{2}{|c|}{ Bekar } & \multicolumn{4}{|c|}{ Ortalamaların Homojenliğiyle İlgili t Testi } \\
\hline & Sayı & Ort. & Sayı & Ort. & $\mathbf{F}$ & $\mathbf{T}$ & df & Sig.(p) \\
\hline NTKSC & 300 & 2,174 & 92 & 2,413 & 0,001 & $-1,998$ & 390 & 0,036 \\
\hline KOBPGGC & 300 & 1,480 & 92 & 1,608 & 0,735 & $-1,613$ & 390 & 0,085 \\
\hline KOZFC & 300 & 1,234 & 92 & 1,292 & 0,769 & $-1,211$ & 390 & 0,240 \\
\hline KAC & 300 & 1,237 & 92 & 1,345 & 7,933 & $-2,248$ & 390 & 0,028 \\
\hline YD & 300 & 3,111 & 92 & 3,241 & 2,613 & $-1,124$ & 390 & 0,285 \\
\hline
\end{tabular}

Tablo 3'te görüldüğü üzere izlenim yönetimi taktikleri alt boyutlarından olan niteliklerini tanıtarak kendini sevdirmeye çalışma ve kendine acındırmaya çalışma taktiklerinde medeni duruma göre farklılık gösterdikleri $(\mathrm{p}<0,05)$ bulgularına ulaşılmıştır. İzlenim yönetimi taktikleri alt boyutundan olan niteliklerini tanıtarak kendini sevdirmeye çalışma ve kendine acındırmaya çalışma taktiğinde, bekar çalışanların ortalamalarının evli çalışanlara göre daha yüksek olduğu görülmektedir. Yaşam doyumu düzeyinde ise medeni durum açısından anlamlı bir farklılık bulunamamıştır. 
Fabrikada çalışan iş görenlerin izlenim yönetimi taktikleri alt boyutları ve yaşam doyumları düzeylerinin yaş, eğitim, gelir durumu, mesleki tecrübe ve iş yerindeki tecrübe değişkenlere göre anlamlı bir farklılık gösterip göstermediği belirlemek için ANOVA analizi uygulanmıştır. Yapılan analiz sonucunda yaş, eğitim ve mesleki tecrübe değişkenine göre anlamlı bir farklılık oluşturmadığı bulgularına ulaşılmıştır. İzlenim yönetimi taktikleri alt boyutlarında gelir durumu ve iş yerindeki tecrübe değişkenlerine göre anlamlı bir farklılık oluşturduğu, yaşam doyumunda ise sadece gelir durumunda anlamlı bir farkl11ık oluşturduğu, bulgularına ulaşılmıştır. Anlamlı farklılıkların hangi gruplar arasında olduğunu belirlemek için Post Hoc tekniklerinden Scheffe Testi uygulanmıştır.

Tablo 4. İzlenim yönetimi taktikleri ile yaşam doyumu düzeylerinin gelir durumuna göre farklılı̆̆ını gösteren Anova testi

\begin{tabular}{|c|c|c|c|c|c|}
\hline Faktörler & Gruplar & Ortalama & SS. & Sig.(P) & Fark \\
\hline \multirow[t]{4}{*}{ NTKSC } & 2000 ve alt 1 & 1,898 & 0,798 & \multirow{4}{*}{$\mathbf{0 , 0 0 0}$} & \\
\hline & $2001-2500$ & 2,329 & 0,938 & & $2001-2500>2000$ ve alt1 \\
\hline & $2501-3500$ & 2,633 & 1,198 & & $2501-3500>2000$ ve alt 1 \\
\hline & 3500 ve üzeri & 2,160 & 0,903 & & \\
\hline \multirow[t]{4}{*}{ KOBPGGC } & 2000 ve alt1 & 1,465 & 0,598 & \multirow{4}{*}{0,782} & \multirow{4}{*}{-} \\
\hline & $2001-2500$ & 1,530 & 0,638 & & \\
\hline & $2501-3500$ & 1,542 & 0,638 & & \\
\hline & 3500 ve üzeri & 1,446 & 0,627 & & \\
\hline \multirow[t]{4}{*}{ KOZFC } & 2000 ve alt1 & 1,160 & 0,347 & \multirow{4}{*}{0,004} & \multirow{4}{*}{3500 ve üzeri $>2000$ ve alt 1} \\
\hline & $2001-2500$ & 1,266 & 0,432 & & \\
\hline & $2501-3500$ & 1,266 & 0,348 & & \\
\hline & 3500 ve üzeri & 1,542 & 0,664 & & \\
\hline \multirow[t]{4}{*}{ KAC } & 2000 ve alt1 & 1,199 & 0,339 & \multirow{4}{*}{0,114} & \multirow{4}{*}{-} \\
\hline & $2001-2500$ & 1,283 & 0,374 & & \\
\hline & $2501-3500$ & 1,270 & 0,331 & & \\
\hline & 3500 ve üzeri & 1,388 & 0,474 & & \\
\hline \multirow[t]{4}{*}{ YD } & 2000 ve altı & 3,050 & 1,051 & \multirow{4}{*}{$\mathbf{0 , 0 3 4}$} & \multirow{4}{*}{$2501-3500>3500$ ve üzeri } \\
\hline & $2001-2500$ & 3,179 & 1,017 & & \\
\hline & $2501-3500$ & 3,410 & 0,884 & & \\
\hline & 3500 ve üzeri & 2,587 & 0,898 & & \\
\hline
\end{tabular}

Analiz sonucunda niteliklerini tanıtarak kendini sevdirmeye çalışma ve kendi önemini zorla fark ettirmeye çalışma taktikleri gelir durumuna göre istatistiksel açıdan anlamlı bir farklılık $(\mathrm{p}<0,05)$ göstermektedir. Scheffe Testi sonuçlarına göre niteliklerini tanıtarak kendini sevdirmeye çalışma taktiğinde, farklılaşma 2001-2500TL gelir durumu sahip olanların ortalamalarından kaynaklanmaktadır. Kendi önemini zorla fark ettirmeye çalışma taktiğinde ise 3500TL ve üzeri gelir durumuna sahip olan çalışanların ortalamalarının, 2000TL ve altı gelir durumuna sahip olan çalışanlardan daha yüksek olduğu tespit edilmiştir. 
Yaşam doyumu düzeyinde de gelir durumuna göre anlamlı bir farklılık bulunmuştur ( $\mathrm{p}<0,05)$. 2501-3500TL gelir durumuna sahip olan çalışanların ortalamalarının, 3500TL ve üzeri gelir durumuna sahip olan çalışanlara göre daha yüksek olduğu görülmektedir.

Tablo 5. İzlenim yönetimi taktikleri ile yaşam doyumu düzeylerinin iş yerlerindeki tecrübelerine göre farklılığını gösteren Anova testi

\begin{tabular}{|c|c|c|c|c|c|}
\hline Faktörler & Gruplar & Ortalama & S.S. & Sig.(P) & Fark \\
\hline \multirow[t]{5}{*}{ NTKSC } & $0-5$ y1l & 2,323 & 0,939 & \multirow{5}{*}{0,009} & \multirow{5}{*}{$0-5$ y1l>11-15 y1l } \\
\hline & $6-10 \mathrm{y} 11$ & 2,295 & 1,042 & & \\
\hline & $11-15$ y1l & 1,823 & 0,800 & & \\
\hline & $16-20 \mathrm{y} 1 \mathrm{l}$ & 2,234 & 1,045 & & \\
\hline & 21 yıl ve üzeri & 2,071 & 0,814 & & \\
\hline \multirow[t]{5}{*}{ KOBPGGC } & $0-5$ y1l & 1,521 & 0,623 & \multirow{5}{*}{0,386} & \\
\hline & 6-10 y1l & 1,575 & 0,684 & & \\
\hline & $11-15 \mathrm{y} 11$ & 1,373 & 0,533 & & \\
\hline & $16-20 \mathrm{y}_{11}$ & 1,506 & 0,662 & & \\
\hline & 21 yıl ve üzeri & 1,666 & 0,684 & & \\
\hline \multirow[t]{5}{*}{ KOZFC } & $0-5$ y1l & 1,251 & 0,401 & \multirow{5}{*}{0,478} & \\
\hline & $6-10 y_{11}$ & 1,264 & 0,460 & & \\
\hline & $11-15 \mathrm{y} 1 \mathrm{l}$ & 1,230 & 0,464 & & \\
\hline & $16-20 \mathrm{y} 1 \mathrm{l}$ & 1,149 & 0,284 & & \\
\hline & 21 yıl ve üzeri & 1,424 & 0,611 & & \\
\hline \multirow{5}{*}{$\mathrm{KAC}$} & $0-5$ y1l & 1,287 & 0,383 & \multirow{5}{*}{0,548} & \\
\hline & $6-10$ y1l & 1,227 & 0,268 & & \\
\hline & $11-15 \mathrm{y} 11$ & 1,207 & 0,381 & & \\
\hline & $16-20 \mathrm{y} 1 \mathrm{l}$ & 1,262 & 0,382 & & \\
\hline & 21 yıl ve üzeri & 1,232 & 0,371 & & \\
\hline \multirow{5}{*}{ YD } & $0-5$ y1l & 3,160 & 1,006 & \multirow{5}{*}{0,117} & \\
\hline & $6-10$ y1l & 3,236 & 0,944 & & \\
\hline & $11-15 \mathrm{y} 11$ & 3,084 & 1,066 & & \\
\hline & $16-20$ y1l & 3,192 & 1,106 & & \\
\hline & 21 yıl ve üzeri & 2,320 & 1,025 & & \\
\hline
\end{tabular}

Tablo 5'te görüldüğü üzere sadece niteliklerini tanıtarak kendini sevdirmeye çalışma taktiğinde anlamlı bir farklılık $(\mathrm{p}<0,05)$ bulunmuştur. İşyerlerinde $0-5$ yıldır çalışanların ortalamalarının, 11-15 yıldır çalışanlara göre daha fazla olduğu görülmektedir. Yaşam doyumu düzeyinin iş yerlerindeki tecrübelerine göre anlamlı bir farklılık göstermediği $(p>0,05)$ tespit edilmiştir.

\subsection{Hipotezlere Yönelik Bulgular}

Araştırma hipotezleri doğrultusunda çalışanların izlenim yönetimi taktiklerinin alt boyutları ile yaşam doyumu arasındaki anlamlı bir ilişkinin olup olmadığını belirlemek amacıyla korelasyon analizi yapılmıştır. Tekstil fabrikasında çalışan bireylerin izlenim yönetimi taktiklerinin alt boyutları ve yaşam doyumu arasındaki ilişkiye yönelik bulgular Tablo 6'da gösterilmektedir. 
Tablo 6. İzlenim yönetimi taktikleri ile yaşam doyumu arasındaki ilişkiye yönelik korelasyon analizi

\begin{tabular}{|lccccc|}
\hline & NTKSC & KOBPGGC & KOZFC & KAC & YD \\
\hline NTKSC & 1 & & & & \\
KOBPGGC & $0,442^{* *}$ & 1 & & & \\
KOZFC & $0,285^{* *}$ & $0,418^{* *}$ & 1 & & \\
KAC & $0,320^{* *}$ & $0,312^{* *}$ & $0,417^{* *}$ & 1 & \\
YD & $0,204^{* *}$ & $-0,048$ & $-0,074$ & $-0,044$ & 1 \\
\hline
\end{tabular}

$* * \mathrm{p}<0,01 * \mathrm{p}<0,05$

Tablo 6'da izlenim yönetimi taktikleri alt boyutları ile yaşam doyumu arasındaki ilişkiyi gösteren korelasyon tablosu incelendiğinde; niteliklerini tanıtarak kendini sevdirmeye çalışma taktiği ile yaşam doyumu arasında çok zayıf (Kalaycı, 2009) ve pozitif yönde anlamlı bir ilişki $(r=0,204, p<0,01)$ bulunmuştur. Fakat kendini örnek bir personel gibi göstermeye çalışma ( $r=-$ 0,048 p>0,05), kendi önemini zorla fark ettirmeye çalışma $(r=-0,074$ p>0,05), kendine acındırmaya çalışma $(\mathrm{r}=-0,044 \mathrm{p}>0,05)$ taktikleri ile yaşam doyumu arasında anlamlı bir ilişki bulunamamıştır. Hipotezlere yönelik yapılan analiz sonuçları Tablo 7'de özet olarak gösterilmiştir.

Tablo 7. Hipotezlerin red/kabul durumu

\begin{tabular}{|c|l|c|}
\hline H & \multicolumn{1}{|c|}{ HİPOTEZLER } & \multicolumn{1}{|c|}{ SONUÇ } \\
\hline H1 & $\begin{array}{l}\text { Niteliklerini tanıtarak kendini sevdirmeye çalışma taktiği ile yaşam doyumu } \\
\text { arasında istatistiksel olarak anlamlı bir ilişki vardır. }\end{array}$ & DESTEKLENDİ \\
\hline $\mathbf{H 2}$ & $\begin{array}{l}\text { Kendini örnek bir personel gibi göstermeye çalışma taktiği ile yaşam doyumu } \\
\text { arasında istatistiksel olarak anlamlı bir iliş̧ki vardır. }\end{array}$ & DESTEKLENMEDİ \\
\hline $\mathbf{H 3}$ & $\begin{array}{l}\text { Kendi önemini zorla fark ettirmeye çalışma taktiği ile yaşam doyumu arasında } \\
\text { istatistiksel olarak anlamlı bir ilişki vardır. }\end{array}$ & DESTEKLENMEDİ \\
\hline $\mathbf{H 4}$ & $\begin{array}{l}\text { Kendine acındırmaya çalışma taktiği ile yaşam doyumu arasında istatistiksel } \\
\text { olarak anlamlı bir ilişki vardır. }\end{array}$ & DESTEKLENMEDİ \\
\hline
\end{tabular}

\section{SONUÇ VE TARTIŞMA}

Bireyler gerek sosyal hayatlarında gerekse iş hayatlarında içinde bulundukları ortam gereği sürekli diğer bireylerle etkileşim ve iletişim halindedirler. Bu etkileşim ve iletişim halinde olduğu diğer bireyler tarafından da kendisine değer verilmesini istemekte ve kendisinin değerli olduğunu hissetmek istemektedir. Bir başka deyişle birey aslında olumlu duygulanım elde etmek istemektedir. Olumlu duygulanım elde etmek içinde bir takım izlenim yönetimi taktiklerine başvurmaktadır. Birey izlenim yönetimi taktilerine başvurarak bulunduğu ortamda maddi ve manevi kazanım elde etme gayesi gütmektedir. Bireyin gaye edindiği maddi ve 
manevi kazanımlar yaşamlarıyla da doğrudan veya dolaylı olarak alakalı olduğu düşüncesiyle araştırmanın amacı izlenim yönetimi taktikleri ile yaşam doyumu arasındaki ilişkiyi incelemek olmuştur.

Yapılan bu araştırmada izlenim yönetimi taktikleri alt boyutları ile yaşam doyumu arasındaki ilişkiye bakılmıştır. Ayrıca katılımcılardan elde edilen demografik verilerle izlenim yönetimi taktileri alt boyutları ve yaşam doyumu düzeylerinin farklılıkları incelenmiştir.

Yapılan araştırmada katılımcıların demografik özelliklerine ait veriler incelendiğinde özetle şunlar söylenebilir: Fabrikada çalışan katılımcıların çoğunluğunu kadın çalışanların oluşturduğu $(\% 59,9)$, eğitim durumlarının çok yüksek olmadığı (lise ve altı \%85,5), evli grubun $(\% 76,5)$ çoğunluğu oluşturduğu ve mesleki tecrübenin $(0-5$ y1l \%31,6) çok fazla olmadığ1 görülmektedir. Buradan hareketle katılımcıların demografik özelliklerinden yola çıkarak sektörün genel karakteristik yapısına benzediğinden söz edilebilir.

Araştırma sonuçlarına göre, fabrikada çalışan bireylerin en fazla izlenim yönetimi taktikleri alt boyutlarından niteliklerini tanıtarak kendini sevdirmeye çalışma taktiği olduğu bulgularına ulaşılmıştır. Daha sonra sırasıyla kendini örnek bir personel gibi göstermeye çalışma, kendine acındırmaya çalışma ve kendi önemini zorla fark ettirmeye çalışma taktikleri gelmektedir. Buradan hareketle fabrikada çalışan bireylerin en yüksek niteliklerini tanıtarak kendini sevdirmeye çalışma taktiği ile bireyler, diğer bireylere yeteneklerini ve niteliklerini duyurarak becerikli, her işin üstesinden gelebilecek birisi olduğu imajı vermek istemektedir. En düşük puanı alan kendi önemini zorla fark ettirmeye çalışma taktiğidir. Yani fabrikada çalışan bireyler diğer bireylere karşı tehdit, gözdağı verme gibi olumsuz duygulanım vermekten kaçındıklarını göstermektedir.

İzlenim yönetimi taktileri tüm alt boyutlarından elde edilen puanların cinsiyet değişkeni açısından anlamlı farklılık gösterdiği bulgularına ulaşılmıştır. Fabrikada çalışan erkek bireylerin kadın bireylere göre daha fazla izlenim yönetimi taktiklerini kullandıkları belirlenmiştir. Literatürde de yapılan bazı araştırmalarda izlenim yönetimi taktikleri kullanımının cinsiyet değişkenine göre farklılık gösterdiğini belirtmektedir (Singh ve Vinnicombe 2001; Mustaffa vd., 2014). Ayrıca Yavuz (2018) üniversite öğrencileri üzerine yaptığı araştırma da benzer sonuçlar bularak niteliklerini tanıtma, örnek davranışlar sergileme ve kendini sevdirme taktiklerinin cinsiyet değişkeni açısından anlamlı farklılıklar bularak erkeklerin daha fazla taktik kullandıkları bulgularına ulaşmıştır. 
Niteliklerini tanıtarak kendini sevdirmeye çalışma ve kendine acındırmaya çalışma taktiklerinden elde edilen puanların medeni durum değişkeni açısından anlamlı farklılık göstermektedir. Her iki taktikte de bekar çalışanların evli çalışanlara göre daha fazla taktik kullandıkları belirlenmiştir. Literatürde yapılan bazı araştırmalarda izlenim yönetimi taktikleri kullanımının medeni duruma göre farklılık göstermediği görülmektedir (Demiral, 2013; Yiğit, 2018). Fakat Mumcu (2018)'nun banka çalışanları üzerine yaptığı araştırmada ise, niteliklerini tanıtarak kendini sevdirmeye çalışma ve karşısındakini yücelterek kendini sevdirmeye çalışmak taktiklerinin medeni durum değişkeni açısından anlamlı bir farklılık gösterdiği tespit edilmiştir.

İzlenim yönetimi taktilerinin yaş değişkeni ve eğitim düzeyi açısından anlamlı farklılık göstermediği tespit edilmiştir. İnceelli (2015)'nin çalışması yaş değişkeni konusunda Kalyoncu (2017)'nun çalışması eğitim düzeyi konusunda benzer sonuçları içermektedir. Niteliklerini tanıtarak kendini sevdirmeye çalışma ve kendi önemini zorla fark ettirmeye çalışma taktiğinin gelir düzeyi değişkeni açısından anlamlı bir farklılık gösterdiği bulunmuştur. Binay ve Yıldız (2017) ise kamu çalışanları üzerine yaptıkları araştırmada kendini örnek bir personel gibi gösterme taktiğinin gelir düzeyine göre farklılaştığı bulgularına ulaşmıştır. İş yerindeki tecrübe değişkeni ile yapılan analiz sonucunda sadece niteliklerini tanıtarak kendini sevdirmeye çalışma taktiğinde anlamlı bir farklılık gösterdiği bulgularına ulaşılmıştır. Demiral (2013)'ın çalışması da benzer sonuçları içermektedir.

Yaşam doyumu düzeylerinden elde edilen puanların cinsiyet, medeni durum, yaş, eğitim durumu ve işyerindeki tecrübe değişkeni açısından anlamlı farklılık yaratmadığı bulgularına ulaşılmıştır. Literatürde cinsiyetin yaşam doyumu üzerindeki etkisinin çok az olduğu bulgularına ulaş1lmıştır (Inglehart, 1990; Michalos, 1991). Medeni duruma göre yaşam doyumunda anlamlı bir farklılık olmadığı (Batan, 2016; Bilge vd., 2009; Aysan ve Bozkurt, 2004), yaş değişkenine göre anlamlı bir farklılık olmadığı (Başoğlu vd., 2016; Acar, 2010), sonucuna yönelik çalışmalar bulunmaktadır. Eğitim durumuna göre farklılığın olmadığı çalışmalar (Toplanır, 2018; Deveci, 2014) olmakla beraber, Özer (2001)'in çalışmasında anlamlı bir farklılık olduğu tespit edilmiştir. Analiz sonuçlarında işyerindeki tecrübesine göre yaşam doyumlarında anlamlı bir farklılık bulunmazken, Akgün (2009) anlamlı bir farklılık bulmuştur. Yaşam doyumu düzeylerinin gelirlerine göre ise anlamlı bir farklılaşma gösterdiği tespit edilmiştir. Yılmaz ve Altınok (2009) gelir düzeyine göre yaşam doyumunda anlamlı bir farklılık bulurken, bazı araştırmalarda (Toseland ve Sykes, 1977; Grün vd., 2010) gelir düzeyi değişkeninin yaşam doyumuna etki etmediği bulunmuştur. 
Araştırmanın ana amacı doğrultusunda oluşturulan hipotezlerin test sonuçlarına göre ise "niteliklerini tanıtarak kendini sevdirmeye çalışma taktiği ile yaşam doyumu arasında istatistiksel olarak anlamlı bir ilişki vardır" şeklinde kurulan H1 hipotezi desteklenmiştir. Ayrıca ilişkinin yönü pozitif olmakla birlikte literatürde de Acaray ve Günsel (2017)'in yapmış olduğu çalışma bu sonucu destekler niteliktedir. Ancak "kendini örnek bir personel gibi göstermeye çalışma taktiği ile yaşam doyumu arasında istatistiksel olarak anlamlı bir ilişki vardır." şeklinde kurulan H2, "kendi önemini zorla fark ettirmeye çalışma taktiği ile yaşam doyumu arasında istatistiksel olarak anlamlı bir ilişki vardır.” şeklinde kurulan H3 hipotezi ve "kendine acındırmaya çalışma taktiği ile yaşam doyumu arasında istatistiksel olarak anlamlı bir ilişki vardır.” şeklinde kurulan H4 hipotezleri desteklenmemiştir.

Sonuç olarak çalışanlar, niteliklerini tanıtarak kendini sevdirmeye çalışma taktiğini kullanarak amacına yönelik eğitim, deneyim ve becerileri ile ilgili niteliklerini diğer kişilere aktararak saygınlık kazanması, terfi elde etmesi, daha fazla ücret olanağına sahip olması ile yaşam doyumunu artırmaktadır. Bunun nedeni çalışma yaşamında artan başarı beraberinde hem iş yaşamında hem de özel yaşamında pek çok olumlu sonuçlar getirecektir (Acaray ve Günsel 2017: 542).

Araştırmanın kısıtları ve araştırmadan elde edilen bulgular doğrultusunda şunlar söylenebilir; Araştırmanın ana kütlesi Denizli ilindeki tekstil fabrikaları ile sınırlıdır. İleride yapılacak olan çalışmalarda izlenim yönetimi taktikleri ile yaşam doyumu arasındaki ilişkiyi diğer illerdeki tekstil fabrikalarında yapılması veya diğer sektörler üzerinde yapılmasıyla farklı sonuçlara ulaşılabileceği düşünülmektedir. $\mathrm{Bu}$ araştırma, tekstil fabrikalarında mavi yakalı çalışanlar üzerinde yapılmıştır. İleride yapılacak olan araştırmalarda, beyaz yakalı çalışanlar üzerinde de yapılıp mavi yakalı ve beyaz yakalı çalışanların kullandıkları izlenim yöntemi taktikleri karşılaştırılabilir. Araştırma değişkenleri ile ilgili ayrı ayrı literatürde birçok çalışma bulunmasına rağmen ikisinin bir arada bulunduğu çalışma yok denecek kadar azdır. Gelecekteki çalışmalarda izlenim yönetimi ile kişilik, lider-üye etkileşimi, örgütsel bağlılık gibi değişkenlerle ilişkisi araştırılabilir.

\section{REFERENCES / KAYNAKLAR}

Acar-Arasan, B. N. (2010). Akademisyenlerde yaşam doyumu iş doyumu ve mesleki tükenmişlik düzeylerinin belirlenmesine yönelik bir araştırma (Yüksek lisans tezi). Uşak Üniversitesi Sosyal bilimler Enstitüsü, Uşak. 
Acaray, A. \& Günsel, A. (2017). Beş faktör kişilik özellikleri, izlenim yönetimi taktikleri ve öznel iyi oluş arasındaki ilişskinin incelenmesi: Kamu çalışanları üzerine bir araştırma. Uluslararası İktisadi ve İdari İncelemeler Dergisi (16. UİK Özel Sayıs1), 527-546.

Akgün, T. (2009). İzlenim yönetimi taktikleri ile iş performansı değerleme puanları arasındaki ilişki: Bir uygulama (Yüksek lisans tezi). Marmara Üniversitesi Sosyal Bilimler Enstitüsü, İstanbul.

Aksu, G., Eser, M.T. \& Güzeller C.O. (2017). Açımlayıcı ve doğrulayıcı faktör analizi ile yapısal eşitlik modeli uygulamaları. Ankara: Detay Yayıncılık.

Aronson, E., Wilson, T.D. \& Akert, R.M. (2010). Sosyal psikoloji (O. Gündüz, Çev.). İstanbul: Kaknüs Yayınları.

Aysan, F. \& Bozkurt, N. (2004). Okul psikolojik danışmanlarının yaşam doyumu, stresle başa çıkma stratejileri ile olumsuz otomatik düşünceleri: İzmir ili örneklemi. XIII. Ulusal Eğitim Bilimleri Kurultayl, 6-9 Temmuz 2004, İnönü Üniversitesi, Eğitim Fakültesi, Malatya.

Basım, H. N. \& Tatar, İ. (2006). Kamuda izlenim yönetimi: Karşıllaştırmalı bir çalışma. Amme İdaresi Dergisi, 39(4), 225-244.

Basım, H. N., Tatar, İ. \& Şahin, N. H. (2006a). İzlenim yönetiminde kendilik algısı, kontrol odağı, mesleki hedeflere ulaşma düzeyi ve stres: Bir kamu sektörü örneği. Türk Psikoloji Dergisi, 21(58), 1-14.

Basım, H. N., Tatar, İ. \& Şahin, N. H. (2006). Çalışma yaşamında izlenim yönetimi: Bir ölçek uyarlama çalışması. Türk Psikoloji Yazıları, 9(18), 1-17.

Başoğlu, B., Şekeroğlu, M., Ö. \& Altun, E. (2016). Öğretmenlerin aile-iş çatışması ve iş-aile çatışmalarının yaşam doyumuna etkisi ve bazı demografik özelliklere göre incelenmesi. Akademik Sosyal Araştırmalar Dergisi, 4(32), 227-291.

Batan, S. N. (2016). Yetişkinlerde psikolojik dayanıklılık ve dini başa çıkmanın yaşam doyumuna etkileri (Doktora tezi). Marmara Üniversitesi Sosyal Bilimler Enstitüsü, İstanbul.

Bektaş M. \& Karagöz Ş. (2018). İzlenim yönetimi davranışının işe tutkunluğa etkisinde sosyal görünüş kaygısının aracılık rolü. Sosyal Araştırmalar ve Davranış Bilimleri Dergisi, 4(6), 275-299.

Beyhan, T. E. (2018). Sağlık çalışanlarının işe hazır bulunuşluk durumlarının öz yeterlilik ve yaşam doyumu üzerine etkisinin değerlendirilmesi (Yüksek lisans tezi). Marmara Üniversitesi Sağlık Bilimleri Enstitüsü, İstanbul.

Bilge, F., Sayan, A. \& Kabakçı, Ö. F. (2009). Aile mahkemesi uzmanlarının meslek doyumları, yaşam doyumları ve ilişkilerine yönelik inançlarının incelenmesi. Türk Psikolojik Danışma ve Rehberlik Dergisi, 4(32), 20-31.

Binay, M. \& Yıldız, S. S. (2017). Kamu çalışanlarının demografik özelliklerine göre örgütsel adalet algısı ve izlenim yönetimi davranışlarının farklılaşması. Journal of Turkish Court of Accounts/Sayistay Dergisi, 107, 127129.

Dağlı, A. \& Baysal, N. (2016). Yaşam doyumu ölçeğinin Türkçe’ye uyarlanmasi: Geçerlik ve güvenirlik çalışması. Elektronik Sosyal Bilimler Dergisi, 15(59), 1250-1262.

Dal, E. (2015). Kadınlardaki duygusal zekâ düzeyi ile yaşam doyumu arasındaki ilişkinin incelenmesi (Yüksek lisans tezi). Üsküdar Üniversitesi Sağlık Bilimleri Enstitüsü, İstanbul.

Demir, K. (2002). Türkiye’deki resmi ve özel lise öğretmenlerinin izlenim yönetimi (Doktora tezi). Ankara Üniversitesi Eğitim Bilimleri Enstitüsü, Ankara.

Demiral, A. (2016). İzlenim yönetiminin olumsuz örgütsel sonuçlara etkisi ve performans değerlemenin aracılık rolü: Türkiye'deki lider şirketlerden ampirik bulgular. Niğde Üniversitesi İktisadi ve İdari Bilimler Dergisi, 9(1), 43-66.

Demiral, Ö. (2013). İzlenim yönetimi taktiklerinin örgütsel sonuçlara etkisi üzerine bir araştırma (Doktora tezi). Çukurova Üniversitesi Sosyal Bilimler Enstitüsü, Adana. 


\section{Hasçeltik, Z. \& Özmen, M.}

DePaulo, B. M. (1992). Nonverbal behavior and self-presentation. Psychological Bulletin, 111(2), $203-243$.

Deveci S. (2014). Sağlık çalışanlarında iş doyumu ve yaşam doyumu ilişkisi (Antalya Atatürk Devlet Hastanesi hemşireler örneği) (Yüksek lisans tezi). Beykent Üniversitesi Sosyal Bilimler Enstitüsü, İstanbul.

Diener, E. D., Emmons, R. A., Larsen, R. J. \& Griffin, S. (1985). The satisfaction with life scale. Journal of Personality Assessment, 49(1), 71-75.

Diener, E., Napa-Scollon, C. K., Oishi, S., Dzokoto, V. \& Suh, E. M. (2000). Positivity and the construction of life satisfaction judgments: Global happiness is not the sum of its parts. Journal of Happiness Studies, 1(2), 159176.

Doğan, S. \& Kılıç, S. (2009). Örgütlerde “izlenim yönetimi davranışı” üzerine kavramsal bir inceleme. Atatürk Üniversitesi İktisadi ve İdari Bilimler Dergisi, 23(3), 53-83.

Dost, M. T. (2007). Üniversite öğrencilerinin yaşam doyumunun bazı değişkenlere göre incelenmesi. Pamukkale Üniversitesi Ĕ̈itim Fakültesi Dergisi, 2(22), 132-143.

Elevli Ö. \& Bayram A. (2019). Yaşam doyumunun iş doyumuna etkisinde sosyal zekanın aracı rolü. BAİB̈̈ Sosyal Bilimler Enstitüsü Dergisi, 19(1), 25-41.

Erhardt N. \& Gibbs J.L. (2014). The dialectical nature of impression management in knowledge work: Unpacking tensions in media use between managers and subordinates. Management Communication Quarterly, 28(2), 155186.

Eroğul, A. R. Ç. \& Örkün, Ü. (2012). Tekstil sektörü mavi yaka çalışanlarının yaşam doyumu ve tükenmişlik düzeylerinin iş doyumu tarafından yordanması. Çukurova Üniversitesi Sosyal Bilimler Enstitüsü Dergisi, 21(1), 323-338

Etiler İ. E. (2017). Sekiz haftalık antrenmanda sözel geribildirimin, basketbolda turnike, top sürme, yaşam doyumu ve özyeterlik, üzerine etkisi (Yüksek lisans tezi). Mersin Üniversitesi Eğitim Bilimleri Enstitüsü, Mersin.

Fakunmoju, S. B. (2018). Work ethic and life satisfaction among social workers in massachusetts: the moderating effect of gender. Human Service Organizations: Management, Leadership \& Governance, 42(4), 396-416.

Field, A. (2009). Discovering statistics using SPSS. London: SAGE.

Grün, C., Hauser, W. \& Rhein, T. (2010). Is any job better than no job? Life satisfaction and re-employment. Journal of Labor Research, 31(3), 285-306.

Inglehart, R. (1990). Culture shift in advanced industrial society. Princeton, NJ: Princeton University Press.

İnceelli, A. (2015). İzlenim yönetimi: KKTC sağlık sektöründe karşılaştırmalı bir araştırma (Yüksek lisans tezi). Uluslararası Kıbrıs Üniversitesi Lisansüstü Eğitim-Öğretim ve Araştırma Enstitüsü, Lefkoşa.

İslamoğlu, A. H. \& Alnıaçık, Ü. (2014). Sosyal bilimlerde araştırma yöntemleri. İstanbul: Beta Basım Yayım.

Jan, M. \& Masood, T. (2008). An assessment of life satisfaction among women. Studies on Home and Community Science, 2(1), 33-42.

Jones, E. E. \& Pittman, T. S. (1982). Toward a general theory of strategic self-presentation. Psychological Perspectives of the Self, 1(1), 231-262.

Kalaycı, Ş. (2009). SPSS uygulamalı çok değişkenli istatistik teknikleri. Ankara: Asil Yayın.

Kalyoncu, M. (2017). Turist rehberlerinin paket turlarda kullandıkları izlenim yönetimi tekniklerinin kişisel etkileşim kalitesi üzerine etkisi (Yüksek lisans tezi). Anadolu Üniversitesi Sosyal Bilimler Enstitüsü, Eskişehir.

Kanten, P. \& Kanten, S. (2015). İş yaşamının kalitesinin yaşam doyumu üzerindeki etkisinde iş doyumunun aracılık rolü. Selen Doğan (Ed.), Yaşam doyumu içinde (ss. 39-72). Ankara: Nobel Akademik Yayıncılık. 
Keser, A. (2005). İş doyumu ve yaşam doyumu ilişkisi: Otomotiv sektöründe bir uygulama. Çalışma ve Toplum, 4(1), 77-95.

Meydan, C. H. (2011). Örgütsel ortamda tükenmişliğin izlenim yönetimi taktikleri ile ilişkisi. Eskişehir Osmangazi Üniversitesi İktisadi ve İdari Bilimler Fakültesi Dergisi, 6(2), 287-307.

Michalos, A. C. (1991). Global report on student well-being. New York: Springer Verlag.

Morgenstern, J. (2004). İkisi bir arada: İş hayatında verimlilik ve tatmin (T. Akal, Çev.). İstanbul: Optimist Yayinları.

Mumcu A. (2018). Örgüt ikliminin örgütsel sinizm üzerindeki etkisinde izlenim yönetimi taktikleri ve lider-üye etkileşiminin aracılık rolü (Yüksek lisans tezi). Gaziosmanpaşa Üniversitesi Sosyal Bilimler Enstitüsü, Tokat.

Mustaffa CS., Marzuki NA., Ariffin MT., Salleh NA. \& Rahaman NH. (2014). Relationship between social support, impression management and well-being among flood victims in Malaysia. Procedia-Social and Behavioral Sciences, 155, 197-202.

Neugarten, B. L., Havighurst, R. J. \& Tobin, S. S. (1961). The measurement of life satisfaction. Journal of Gerontology, 16, 134-143.

Özer M. (2001). Huzurevinde ve aile ortamında yaşayan yaşllların öz bakım gücü ve yaşam doyumunun incelenmesi. Ege Üniversitesi Sağlık Bilimleri Enstitüsü, İzmir.

Schütz, A. (1998). Assertive, offensive, protective, and defensive styles of selfpresentation-a taxonomy. Journal of Psychology, 132(6), 611-628.

Serin, A.E., Balkan, M.O. \& Soran, S. (2014). Çatışma yönetim stratejilerinin izlenim yönetimi taktiklerine etkisi: Üniversite öğrencileri üzerine bir araştırma. Elektronik Sosyal Bilimler Dergisi, 13(50), 23-37.

Singh, V. \& Vinnicombe, S. (2001). Impression management, commitment and gender: Managing others' good opinions. European Management Journal, 19(2), 183-194.

Sung, K. W. (2003). Influencing variables on life satisfaction of Korean Elders in institutions. Journal of Korean Academy of Nursing, 33(8), 1093-1100.

Şimşek, E. \& Aktaş, H. (2015). İletişim becerileri bağlamında yalnızlık ve yaşam doyumu ilişkisi. Selen Doğan (Ed.), Yaşam doyumu içinde (ss.147-178). Ankara: Nobel Akademik Yayıncılık.

Toplanır, E. (2018). Yaşam doyumu kendini gerçekleştirme ve ölüm korkusu arasındaki ilişkinin incelenmesi (Yüksek lisans tezi). Haliç Üniversitesi Sosyal Bilimler Enstitüsü, İstanbul.

Toseland, R. \& Sykes, J. (1977). Senior citizens center participation and other correlates of life satisfaction. The Gerontologist, 17(3), 235-241.

Toy, A. B. (2015). Serbest ve grekoromen stil güreşçilerin hedef yönelimi ve yaşam doyumu ilişkisi (Yüksek lisans tezi). Hitit Üniversitesi Sosyal Bilimler Enstitüsü, Çorum.

Trochim, W. \& Donnelly, J. (2006). The research methods knowledge base. Mason, OH: Atomic Dog Publishing.

Ünaldı, S. (2005). Emniyet örgütü yöneticilerinin izlenim yönetimi (Yüksek lisans tezi). Ankara Üniversitesi Eğitim Bilimleri Enstitüsü, Ankara.

Ünal, S., Karlıdağ, R. \& Yoloğlu, S. (2001). Hekimlerde tükenmişlik ve iş doyumu düzeylerinin yaşam doyumu düzeyleri ile ilişkisi. Klinik Psikiyatri, 4(2), 113-118.

Veenhoven, R. (1996). The study of life-satisfaction. In: Saris, W.E., Veenhoven, R., Scherpenzeel, A.C. \& Bunting B. (Eds.) Acomparative study of satisfaction with life in Europe (pp. 11-48). Eötvös University Press. 


\section{Hasçeltik, Z. \& Özmen, M.}

Wayne, S. J. \& Ferris, G. R. (1990). Influence tactics, affect and exchange quality in supervisor-subordinate interactions: A laboratory experiment and field study. Journal of Applied Psychology, 75(5), 487-500.

Yavuz N. (2018). Üniversite öğrencilerinin sosyal medyada kullandıkları izlenim yönetimi taktiklerinin benlik saygısı ile ilişkisinin incelenmesi (Yüksek lisans tezi). Dicle Üniversitesi Sosyal Bilimler Enstitüsü, Diyarbakır.

Yiğit, Ö. A. (2018). Duygusal emek kullanımı ve izlenim yönetimi taktiklerinin tükenmişlik üzerine etkisi: Aile hekimleri örneği (Yüksek lisans tezi). Sivas Cumhuriyet Üniversitesi Sağlık Bilimleri Enstitüsü, Sivas.

Yiğit, R., Dilmaç, B. \& Deniz, M. E. (2011). İş ve yaşam doyumu: Konya emniyet müdürlüğü alan araştırması. Polis Bilimleri Dergisi, 13(3), 1-18.

Yılmaz, E. \& Altınok, V. (2009). Okul yöneticilerinin yalnızlık ve yaşam doyum düzeylerinin incelenmesi. Kuram ve Uygulamada Egitim Yönetimi Dergisi, 15(59), 451-470.

Yılmaz, E. \& Sünbül, A. M. (2009). Öğretmenlerin yaşam doyumları ve okullardaki örgütsel güven düzeyi. Journal of Qafqaz University, 26, 172-179. 